\title{
Effect of Some Food Ingredients on Various Characteristics of Instant Tanier Flakes and Wheat Flour ${ }^{1}$
}

\author{
E. J. Rodríguez-Sosa and M. A. González²
}

\begin{abstract}
The influence of some food ingredients commonly used in breadmaking on various characteristics of instant tanier (Xantohosoma sp.) flakes, wheat flour, and a mixture of $15 \%$ tanier flakes, and $85 \%$ wheat flour (15-85 mixture) was determined. Pasting measurements, taken using the Brabender Amylograph-Viscograph, were higher for samples containing wheat flour. Tanier starch from flakes was stronger than wheat starch. Both starches showed good stability while cooking for 1 hour at 93 and at $50^{\circ} \mathrm{C}$. A peak viscosity was observed in some samples while cooling to $50^{\circ} \mathrm{C}$. In tanier flakes, ingredients tended to decrease pasting measurements while in wheat flour they tended to increase them. Pasting properties of the 15-85 mixture followed the same pattern of wheat flour, but the presence of tanier flakes tended to lower the values. Light reflectance measured after amylography (paste clarity) was higher for wheat flour while shear press (gel texture) tended to be higher for the 15-85 mixture.
\end{abstract}

\section{INTRODUCTION}

Starch contributes greatly to the textural properties of many food systems. Study of the recorded rheological data gives valuable information on the physical changes that may be expected during the processing of products containing starch. The Brabender Amylograph-Viscograph is the instrument most extensively used to determine the changes which occur in starch or flour slurries during heating, cooling, and cooking.

It is recognized that starch is modified by the kind and amount of ingredients added to the food system. Numerous authors have described the effects of sugars, inorganic salts, and other compounds on pasting properties of starch, but few described the effects of these ingredients or mixtures of them on flour. Bean and Osman (1) showed that disaccharides have greater effects on gelatinization of starch than monosaccharides. Osman (6) and Hester et al. (4) found that sucrose retards the swelling of starch granules. Harai et al. (3) found that lactose when added to wheat starch pastes increases viscosity at the recording points. Triglycerides alone lower the gelatinization temperatures or increase swelling (7).

D'Appolonia (2) studied the effect of bread ingredients on the gelatini-

' Manuscript submitted to Editorial Board May 26, 1976.

${ }^{2}$ Assistant Food Technologist and Technical Director, respectively, Food Technology Laboratory, Agricultural Experiment Station, Mayagüez Campus, University of Puerto Rico, Río Piedras, P.R. 
zation properties of starch. He found that sugar increases peak height and that pasting temperature and peak height increased in the presence of $4 \%$ or less salt. He also found that shortenings decreased peak height slightly but increased retrogradation.

Bread and other baked cereal products are among the most important foods worldwide. However, wheat especially appropriate for preparing leavened bread is generally produced in the developed countries.

Traditionally, leavened bread is prepared from wheat or rye flour of high gluten content. Gluten is a protein that due to its elastic properties permits the entrapment of the evolved carbon dioxide during the fermentation of bread increasing loaf volume. Only recently the preparation of bread using flours other than wheat and rye or partially using substitutes for them has been attempted.

Economic and nutritional benefits could be obtained if other nonwheat staples grown in developing countries were substituted for wheat flour in breadmaking. Among these are the starchy crops which are extensively cultivated in most developing countries.

This study was undertaken to determine the influence of some food ingredients, commonly used in breadmaking, on instant tanier (Xanthosoma sp.) flakes, wheat flour, and a mixture of both.

\section{MATERIALS AND METHODS}

Instant tanier flakes were prepared from the white-fleshed cultivar locally known as Rascana, according to the method of Rodríguez-Sosa and González (8). Commercial wheat flour with a high gluten content was used throughout this study. A mixture consisting of $15 \%$ instant tanier flakes and $85 \%$ wheat flour (15-85 mixture) was prepared.

Pasting measurements of the individual flours, that is, instant flakes and wheat flour, and of the 15-85 mixture were taken using the Brabender Amylograph-Viscograph. ${ }^{3}$ Samples were prepared by mixing at room temperature for 30 seconds $65 \mathrm{~g}$ flour with $300 \mathrm{ml}$ distilled water in a Waring Blendor at moderate speed. The slurry thus obtained was poured into the Amylograph bowl. The blender cup was rinsed with 150 $\mathrm{ml}$ distilled water and this water was also poured into the Amylograph bowl. Each food ingredient was first added separately to samples of wheat and tanier flours and their 85/15\% mix. The amounts used were: salt, $2.6 \mathrm{~g}$; sugar, $1.03 \mathrm{~g}$; vegetable shortening, $5.79 \mathrm{~g}$; fresh whole egg, $13.10 \mathrm{~g}$; and yeast, $1.96 \mathrm{~g}$. Same ingredients and amounts were later mixed and added to corresponding flour samples. The Amylograph was

\footnotetext{
${ }^{3}$ Trade names are used in this publication solely for the purpose of providing specific information. Mention of trade names does not constitute a guarantee or warranty of the equipment by the Agricultural Experiment Station of the University of Puerto Rico or an endorsement over other equipment not mentioned.
} 
set at $75 \mathrm{r} / \mathrm{m}$ bowl speed and the $700 \mathrm{~cm} / \mathrm{g}$ sensitivity cartridge was used. Initial viscosity was recorded at room temperature $\left( \pm 27^{\circ} \mathrm{C}\right)$. Samples were heated at $30^{\circ} \mathrm{C}$ to $93^{\circ} \mathrm{C}$ at a constant rate of $1.5^{\circ} \mathrm{C} / \mathrm{min}$ and held at $93^{\circ} \mathrm{C}$ for 1 hour. The starch-flour pastes were then cooled at the same rate to $50^{\circ} \mathrm{C}$ and held at that temperature for another hour.

Yeast, before it was added, was first activated, using the rapidmix method, which consists of dissolving the dehydrated yeast in $50 \mathrm{ml}$ water at between 120 and $130^{\circ} \mathrm{F}\left(48.9-54.4^{\circ} \mathrm{C}\right)$ for 10 minutes. In this case, the water used to rinse the blender cup was reduced to $100 \mathrm{ml}$ to maintain a constant water addition level $(450 \mathrm{ml})$. The activated yeast was added to the slurries and let stand for 45 minutes. When vegetable shortening was added, it was first melted.

Color and shear press measurements were taken at room temperature on samples after the amylographic determination. Color measurements (reflectance) were taken on the whole sample after amylography, using a Color Hunter Difference Meter Model D 25. A white standard tile with the following values was used for comparison: $L=92.8, a=-0.5$, and $b$ $=+2.5$. A Texture Text System provided with a universal cell, a snugly fitted piston, and a bottom plate with an orifice of 0.062 in $(0.157 \mathrm{~cm})$, together with a $300 \mathrm{lb}(136.08 \mathrm{~kg})$ proving ring with the recorder range adjusted to $20 \%$, was used. The stroke of the ram was adjusted to $1 \mathrm{~min}$. Measurements were taken on $150 \mathrm{~g}$ samples. The area under the curve was measured with a planimeter. The maximum force and the ascending and descending lines were measured directly from the curves.

\section{RESULTS AND DISCUSSION}

Table 1 shows the results of the amylographic determinations. Pasting temperatures were higher in samples of group A. Samples in group $\mathrm{B}$ and $\mathrm{C}$ had about the same pasting temperatures, being lower in sample $6 \mathrm{~B}$. Initial viscosities were also higher in samples of group A and ingredients in this group tended to lower them.

Samples in group B and C showed viscosity peaks while cooking to $93^{\circ}$ C. The peaks appeared before reaching $93^{\circ} \mathrm{C}$. Since samples in group A did not show these peaks, except a small one in $2 \mathrm{~A}$, it can be assumed that starch in wheat flour is relatively fragile, while in tanier flakes it is stronger. Probably chlorine ions in salt weaken the hydrogen bonds of starch granules in tanier flakes, provoking the small peak that is observed in sample $2 \mathrm{~A}$.

In general, pasting measurements, except pasting temperature, were higher for samples containing wheat flour than for samples containing tanier flakes. Pasting measurements of group B tended to be higher than those of group $\mathrm{C}$. The reduction in $\mathrm{C}$ could be attributed to the dilution effect when wheat flour and tanier flakes were mixed. 
TABLE 1. - The influence of some food ingredients on pasting properties of slurries of instant tanier flakes, wheat flour, and a blend consisting of $15 \%$ instant tanier flakes and $85 \%$ wheat flour

\begin{tabular}{|c|c|c|c|c|c|c|c|c|}
\hline \multirow[b]{2}{*}{ Samples } & \multirow[b]{2}{*}{$\begin{array}{l}\text { Sample } \\
\text { code }\end{array}$} & \multirow[b]{2}{*}{$\begin{array}{l}\text { Pasting } \\
\text { tempera- } \\
\text { ture }\end{array}$} & \multicolumn{6}{|c|}{ Viscosity Measurements } \\
\hline & & & $\begin{array}{c}\text { Ini- } \\
\text { tial } \\
\text { vis- } \\
\text { cosity }\end{array}$ & $\begin{array}{l}\text { Maxi- } \\
\text { mum } \\
\text { peak }\end{array}$ & $\begin{array}{l}\text { On } \\
\text { reach- } \\
\text { ing } 93^{\circ} \\
\text { C }\end{array}$ & $\begin{array}{l}\text { After } 1 \\
\text { hour at } \\
93^{\circ} \mathrm{C}\end{array}$ & $\begin{array}{l}\text { On } \\
\text { reach- } \\
\text { ing } 50^{\circ} \\
\mathrm{C}\end{array}$ & $\begin{array}{l}\text { After 1 } \\
\text { hour at } \\
50^{\circ} \mathrm{C}\end{array}$ \\
\hline \multicolumn{9}{|l|}{ Group A } \\
\hline Tanier & $1 \mathrm{~A}$ & $75^{\circ} \mathrm{C}$ & 43 & - & 25 & 63 & 168 & 153 \\
\hline Tanier +2.6 g salt & $2 \mathrm{~A}$ & $80^{\circ}$ & 40 & 23 & 18 & 38 & 105 & 95 \\
\hline $\begin{array}{l}\text { Tanier }+1.03 \mathrm{~g} \\
\text { sugar }\end{array}$ & $3 \mathrm{~A}$ & $78^{\circ}$ & 33 & - & 13 & 33 & 93 & 83 \\
\hline $\begin{array}{l}\text { Tanier }+5.79 \mathrm{~g} \\
\text { shortening }\end{array}$ & $4 \mathrm{~A}$ & $80^{\circ}$ & 35 & - & 13 & 28 & 95 & 75 \\
\hline Tanıer + $13.10 \mathrm{~g} \mathrm{egg}$ & $5 \mathrm{~A}$ & $77^{\circ}$ & 33 & - & 30 & 45 & 123 & 113 \\
\hline $\begin{array}{c}\text { Tanier } \\
\text { yeast }\end{array}$ & $6 \mathrm{~A}$ & $77^{\circ}$ & 35 & - & 30 & 53 & 128 & 108 \\
\hline $\begin{array}{l}\text { Tanier + all ingre- } \\
\text { dients }\end{array}$ & $7 \mathrm{~A}$ & $72^{\circ}$ & 40 & - & 88 & 148 & 198 & 145 \\
\hline \multicolumn{9}{|l|}{ Group B } \\
\hline Wheat & $1 \mathrm{~B}$ & $62^{\circ}$ & 15 & 163 & 33 & 44 & 130 & 163 \\
\hline Wheat +2.6 g salt & $2 \mathrm{~B}$ & $63^{\circ}$ & 10 & 358 & 108 & 105 & 290 & 315 \\
\hline $\begin{array}{l}\text { Wheat }+1.03 \mathrm{~g} \\
\text { sugar }\end{array}$ & $3 \mathrm{~B}$ & $62^{\circ}$ & 18 & 210 & 50 & 60 & 170 & 180 \\
\hline $\begin{array}{l}\text { Wheat }+5.79 \mathrm{~g} \\
\text { shortening }\end{array}$ & $4 \mathrm{~B}$ & $62^{\circ}$ & 10 & 220 & 55 & 73 & 195 & 200 \\
\hline Wheat + $13.10 \mathrm{~g}$ egg & $5 \mathrm{~B}$ & $62^{\circ}$ & 10 & 258 & 80 & 78 & 208 & 218 \\
\hline $\begin{array}{c}\text { Wheat }+1.96 \mathrm{~g} \\
\text { yeast }\end{array}$ & $6 \mathrm{~B}$ & $60^{\circ}$ & 10 & 205 & 53 & 53 & 153 & 168 \\
\hline $\begin{array}{l}\text { Wheat + all ingredi- } \\
\text { ents }\end{array}$ & $7 \mathrm{~B}$ & $63^{\circ}$ & 10 & 370 & 120 & 110 & 333 & 300 \\
\hline \multicolumn{9}{|l|}{ Group C } \\
\hline $15 \%-85 \%$ mixture & $1 \mathrm{C}$ & $63^{\circ}$ & 13 & 135 & 40 & 48 & 133 & 173 \\
\hline $\begin{array}{l}15 \%-85 \% \text { mixture }+ \\
2.6 \mathrm{~g} \text { salt }\end{array}$ & $2 \mathrm{C}$ & $65^{\circ}$ & 15 & 275 & 98 & 95 & 257 & 313 \\
\hline $\begin{array}{c}15 \%-85 \% \text { mixture }+ \\
1.03 \mathrm{~g} \text { sugar }\end{array}$ & $3 \mathrm{C}$ & $62^{\circ}$ & 13 & 153 & 40 & 58 & 153 & 188 \\
\hline $\begin{array}{c}15 \%-85 \% \text { mixture }+ \\
5.79 \mathrm{~g} \text { shortening }\end{array}$ & $4 \mathrm{C}$ & $62^{\circ}$ & 10 & 170 & 58 & 70 & 175 & 183 \\
\hline $\begin{array}{l}15 \%-85 \% \text { mixture + } \\
13.10 \mathrm{~g} \text { egg }\end{array}$ & $5 \mathrm{C}$ & $62^{\circ}$ & 13 & 168 & 65 & 63 & 170 & 198 \\
\hline $\begin{array}{l}15 \%-85 \% \text { mixture }+ \\
1.96 \text { g yeast }\end{array}$ & $6 \mathrm{C}$ & $62^{\circ}$ & 10 & 158 & 50 & 58 & 145 & 155 \\
\hline $\begin{array}{l}15 \%-85 \% \text { mixture + } \\
\text { all ingredients }\end{array}$ & $7 \mathrm{C}$ & $63^{\circ}$ & 10 & 378 & 118 & 108 & 278 & 273 \\
\hline
\end{tabular}

No thinning occurred in samples of group A when they were cooked for 1 hour at $93^{\circ} \mathrm{C}$; instead, viscosities increased, denoting that the swelling capacities of starch granules were not reached. No appreciable changes in viscosity occurred in groups B and C while cooking 1 hour at 
$93^{\circ} \mathrm{C}$, denoting the stability of wheat starch after granules rupture (peak viscosity).

Upon cooling, starch molecules reaggregate to form the starch granules, thus increasing viscosity. As expected, these increases were higher for samples in groups B and C.

All samples showed certain degree of stability while cooking at $50^{\circ} \mathrm{C}$ for 1 hour. Changes in viscosity were not great. In samples of group A a small thinning (rupture of granules) occurred while cooking at $50^{\circ} \mathrm{C}$. However, in samples containing wheat flour, except in $7 \mathrm{~B}$ and $7 \mathrm{C}$, an increase in viscosity was observed. It seems that starch granules in those samples continued to reaggregate while cooking at $50^{\circ} \mathrm{C}$. Viscosity values after cooking 1 hour at $50^{\circ} \mathrm{C}$ tended to be higher for samples in group B than for samples in group C. The presence of tanier flakes in group $\mathrm{C}$ reduced these values.

In group $\mathrm{A}$ the ingredients, when individually added, increased in a highly significant way the pasting temperature of tanier flakes. When all the ingredients were added together $(7 \mathrm{~A})$, pasting temperature was reduced from 75 to $72^{\circ} \mathrm{C}$. On reaching $93^{\circ} \mathrm{C}$, all other pasting measurements also decreased in a significant way. Sample $7 \mathrm{~A}$ showed a viscosity peak while cooling to $50^{\circ} \mathrm{C}$. The peak appeared 22 minutes after starting the cooling action. Apparently, a small rupture of starch granules occurred at this point due possibly to both the continuous mechanical stirring of the Amylograph and the overswelling of granules. Because starch molecules reaggregate and form the starch granules upon cooling, presumably at this point starch molecules were still reaggregating and possibly the already formed granules were absorbing water and a momentary rupture occurred.

In group B all samples showed viscosity peaks while heating to $93^{\circ} \mathrm{C}$. Regarding pasting temperature, sample 6 B was significantly lower ( $1 \%$ level) than the others. Ingredients greatly increased viscosity measurements at maximum peak and on reaching $93^{\circ} \mathrm{C}$. In the case of viscosity after 1 hour at $93^{\circ} \mathrm{C}$ and viscosity on reaching $50^{\circ} \mathrm{C}$, except for $6 \mathrm{~B}$, all other samples were significantly higher (1\% level). Finally, samples 3 B and $6 \mathrm{~B}$ after 1 hour at $50^{\circ} \mathrm{C}$ were not significantly different from sample $1 \mathrm{~B}$, but the others were significantly higher. Among ingredients, sugar and yeast provoke the lower viscosity measurements. Samples 2 B and 7 $\mathrm{B}$ showed viscosity peaks while cooling to $50^{\circ} \mathrm{C}$. The former showed the peak 10 minutes after starting the cooling action, the latter after 23 minutes. As in sample $7 \mathrm{~A}$, after those peaks, viscosity returned to normal levels.

With small differences, pasting properties of samples in group C followed a similar pattern to those in group B. As in group B and excepting sample $1 \mathrm{C}$, sugar and yeast showed the lower pasting mea- 
surements. Samples 2 C, 6 C, and 7 C showed viscosity peaks while cooling from $93^{\circ} \mathrm{C}$ to $50^{\circ} \mathrm{C}$. Peaks occurred 12,10 , and 17 min after starting the cooling action, respectively.

Table 2 shows color evaluation of samples. According to Leach, (5) visual estimation of paste clarity is related to light reflectance rather than to light transmission. Paste clarity is directly related to the state of dispersion and retrogradation tendency of the starch. The factors that increase granules swelling and solubilization, or those that inhibit

TABLE 2.- The influence of some food ingredients on color measurements of gels formed after amylography of instant tanier flakes, wheat flour, and a blend consisting of $15 \%$ tanier flakes and $85 \%$ wheat flour

\begin{tabular}{|c|c|c|c|c|}
\hline Samples & $\begin{array}{c}\text { Sample } \\
\text { code }\end{array}$ & $\mathrm{L}$ & a & $\mathrm{b}$ \\
\hline \multicolumn{5}{|l|}{ Group A } \\
\hline Tanier & $1 \mathrm{~A}$ & 53.4 & -.3 & +8.0 \\
\hline Tanier $+2.6 \mathrm{~g}$ salt & $2 \mathrm{~A}$ & 51.6 & +.3 & +7.8 \\
\hline Tanier $+1.03 \mathrm{~g}$ sugar & $3 \mathrm{~A}$ & 52.1 & +.4 & +7.9 \\
\hline Tanier $+5.79 \mathrm{~g}$ shortening & $4 \mathrm{~A}$ & 55.6 & +.3 & +7.9 \\
\hline Tanier + $13.10 \mathrm{~g} \mathrm{egg}$ & $5 \mathrm{~A}$ & 53.7 & -.3 & +8.8 \\
\hline Tanier +1.96 g yeast & $6 \mathrm{~A}$ & 56.5 & -.5 & +9.0 \\
\hline Tanier + all ingredients & $7 \mathrm{~A}$ & 63.9 & -1.6 & +12.2 \\
\hline \multicolumn{5}{|l|}{ Group B } \\
\hline Wheat & $1 \mathrm{~B}$ & 64.1 & -.7 & +8.8 \\
\hline Wheat $+2.6 \mathrm{~g}$ salt & $2 B$ & 64.5 & -.8 & +8.3 \\
\hline Wheat $+1.03 \mathrm{~g}$ sugar & $3 \mathrm{~B}$ & 62.9 & -.4 & +8.6 \\
\hline Wheat +5.79 g shortening & $4 \mathrm{~B}$ & 64.7 & -.9 & +9.0 \\
\hline Wheat $+13.10 \mathrm{~g}$ egg & $5 \mathrm{~B}$ & 68.3 & -1.6 & +12.5 \\
\hline Wheat $+1.96 \mathrm{~g}$ yeast & $6 \mathrm{~B}$ & 61.4 & -.9 & +9.6 \\
\hline Wheat + all ingredients & $7 \mathrm{~B}$ & 67.7 & -2.1 & +12.4 \\
\hline \multicolumn{5}{|l|}{ Group C } \\
\hline $15 \%-85 \%$ mixture & $1 \mathrm{C}$ & 59.1 & -.3 & +5.8 \\
\hline $15 \%-85 \%$ mixture $+2.6 \mathrm{~g}$ salt & $2 \mathrm{C}$ & 60.1 & -.3 & +5.6 \\
\hline $15 \%-85 \%$ mixture $+1.03 \mathrm{~g}$ sugar & $3 \mathrm{C}$ & 58.1 & 0 & +5.8 \\
\hline $15 \%-85 \%$ mixture $+5.79 \mathrm{~g}$ shortening & $4 \mathrm{C}$ & 60.4 & -.3 & +6.2 \\
\hline $15 \%-85 \%$ mixture $+13.10 \mathrm{~g}$ egg & $5 \mathrm{C}$ & 63.9 & -1.2 & +9.9 \\
\hline $15 \%-85 \%$ mixture $+1.96 \mathrm{~g}$ yeast & $6 \mathrm{C}$ & 59.0 & -.9 & +7.6 \\
\hline $15 \%-85 \%$ mixture + all ingredients & $7 \mathrm{C}$ & 62.5 & -1.8 & +10.7 \\
\hline
\end{tabular}

retrogradation, also increase paste clarity. These governing principles partly explain the effects of various adjuncts on paste clarity.

The "L" values (reflectance, table 2) for samples in group A were the lowest and so were retrogradation and swelling (table 1). The higher values for " $L$ " were obtained in samples in group B. Values of "a" are generally in the negative side (greenness). Absolute "a" values were very low. Values for "b" were positive (yellowness) and are higher in group B and lower in group C.

In group $A$, when all ingredients were added " $L$ " values were signifi- 
cantly higher, (1\% level) but significantly lower (1\% level) when salt and sugar alone were added. Samples with salt, sugar, and shortening added were the only ones that gave positive values for "a" values (redness). These values were very low.

For samples in group B, "L" values were significantly higher (1\% level) in $5 \mathrm{~B}$ and lower (5\% level) in $6 \mathrm{~B}$. The "a" values were significantly higher in $7 \mathrm{~B}$ and $5 \mathrm{~B}$ (1\% level) and lower (5\% level) in $3 \mathrm{~B}$. The yellow component was significantly higher (1\% level) for samples $5 \mathrm{~B}$ and $7 \mathrm{~B}$ and lower for sample $2 \mathrm{~B}$. Samples in group C followed the same trend of samples in group B.

Samples after amylography essentially are gels, that is, a substance that has structure and elasticity and can withstand certain degree of change in shape before breaking. Table 3 shows the shear press analyses of samples after amylography. Area under the curve (work applied to the entire sample) measurements were higher for samples in group C

TABLE 3. - The influence of some food ingredients on shear press measurements of gels formed after amylography of instant tanier flakes, wheat flour, and a blend consisting of $15 \%$ tanier flakes and $85 \%$ wheat flour

\begin{tabular}{|c|c|c|c|c|c|}
\hline Samples & $\begin{array}{l}\text { Sample } \\
\text { code }\end{array}$ & $\begin{array}{l}\text { Area } \\
\text { under } \\
\text { the } \\
\text { curve }\end{array}$ & $\begin{array}{l}\text { Maxi- } \\
\text { mum } \\
\text { force }\end{array}$ & $\begin{array}{l}\text { Ascend- } \\
\text { ing line }\end{array}$ & $\begin{array}{l}\text { De- } \\
\text { scend- } \\
\text { ing line }\end{array}$ \\
\hline & & $I n^{2}$ & $L b s$ & Lbs & Lbs \\
\hline \multicolumn{6}{|l|}{ Group A } \\
\hline Tanier & $1 \mathrm{~A}$ & 2.52 & 18.9 & 10.7 & 12.0 \\
\hline Tanier $+2.6 \mathrm{~g}$ salt & $2 \mathrm{~A}$ & 1.89 & 18.2 & 5.4 & 10.3 \\
\hline Tanier $+1.03 \mathrm{~g}$ sugar & $3 \mathrm{~A}$ & 1.95 & 17.0 & 4.9 & 9.6 \\
\hline Tanier + 5.79 g shortening & $4 \mathrm{~A}$ & 1.91 & 17.8 & 5.0 & 9.3 \\
\hline Tanier + 13.10 g egg & $5 \mathrm{~A}$ & 2.05 & 17.9 & 5.8 & 11.6 \\
\hline Tanier + 1.96 g yeast & $6 \mathrm{~A}$ & 2.14 & 13.3 & 6.6 & 11.0 \\
\hline Tanier + all ingredients & $7 \mathrm{~A}$ & 2.04 & 18.5 & 6.9 & 10.1 \\
\hline \multicolumn{6}{|l|}{ Group B } \\
\hline Wheat & $1 \mathrm{~B}$ & 2.85 & 17.4 & 10.2 & 13.6 \\
\hline Wheat $+2.6 \mathrm{~g}$ salt & $2 \mathrm{~B}$ & 6.69 & 35.2 & 26.0 & 32.3 \\
\hline Wheat $+1.03 \mathrm{~g}$ sugar & $3 \mathrm{~B}$ & 3.06 & 24.1 & 11.4 & 16.8 \\
\hline Wheat $+5.79 \mathrm{~g}$ shortening & $4 \mathrm{~B}$ & 2.07 & 11.7 & 6.7 & 9.2 \\
\hline Wheat $+13.10 \mathrm{~g}$ egg & $5 \mathrm{~B}$ & 2.48 & 12.5 & 8.5 & 12.5 \\
\hline Wheat + 1.96 g yeast & $6 \mathrm{~B}$ & 2.51 & 13.1 & 9.4 & 13.1 \\
\hline Wheat + all ingredients & $7 \mathrm{~B}$ & 2.95 & 15.1 & 11.6 & 15.0 \\
\hline \multicolumn{6}{|l|}{ Group C } \\
\hline $15 \%-85 \%$ mixture & $1 \mathrm{C}$ & 3.42 & 31.4 & 14.6 & 17.4 \\
\hline $15 \%-85 \%$ mixture $+2.6 \mathrm{~g}$ salt & $2 \mathrm{C}$ & 6.93 & 34.9 & 27.0 & 30.8 \\
\hline $15 \%-85 \%$ mixture $+1.03 \mathrm{~g}$ sugar & $3 \mathrm{C}$ & 4.02 & 32.4 & 14.0 & 18.7 \\
\hline $15 \%-85 \%$ mixture $+5.79 \mathrm{~g}$ shortening & $4 \mathrm{C}$ & 3.01 & 31.2 & 9.3 & 13.4 \\
\hline $15 \%-85 \%$ mixture $+13.10 \mathrm{~g}$ egg & $5 \mathrm{C}$ & 3,43 & 18.5 & 10.6 & 16.3 \\
\hline $15 \%-85 \%$ mixture +1.96 g yeast. & $6 \mathrm{C}$ & 2.95 & 24.1 & 11.0 & 14.9 \\
\hline $15 \%-85 \%$ mixture + all ingredients & $7 \mathrm{C}$ & 3.72 & 25.6 & 12.4 & 19.3 \\
\hline
\end{tabular}


and lower for samples in group A. Maximum force, which denotes internal structure of gels, are also higher in samples of group C.

The ascending and descending lines, distance from the base line of the chart paper to the plateau of the curve, of the shear press curves are indications of the gel strength. They measure deformation of gels. Ascending and descending lines tended to be higher for samples in group $\mathrm{C}$ and lower in group $\mathrm{A}$. Curves have relatively few peaks, ranging from 7 in group $\mathrm{C}$ to 0 in group B. This indicates the uniformity of gels.

No significant differences were observed among samples in group A, but ingredients tended to soften the gels formed, which, in this group, were very weak. In group $B$, salt had a marked effect in increasing gel strength (significant at 1\% level) while vegetable shortening, egg, and yeast softened the gels. The same trend was observed in group C.

\section{RESUMEN}

Se estudió la influencia que tienen algunos ingredientes usados comunmente en la elaboración del pan, tales como sal, azúcar, grasa, huevo y levadura, en varias características de una harina instantánea de yautia (Xanthosoma sp.), harina de trigo de alto contenido en gluten y una mezcla de ambas consistentes de $15 \%$ de harina instantánea y 85\% de harina de trigo (mezcla 15-85). Las medidas de viscosidad tomadas usando el amiloviscógrafo Brabender fueron más altas para las muestras que contenían harina de trigo. El gel de almidón de yautía en la harina instantánea fue más resistente que el de trigo. Ambos almidones mostraron buena estabilidad cuando se cocinaron a $93^{\circ}$ y $50^{\circ} \mathrm{C}$ por espacio de una hora. Se observó un pico de viscosidad en algunas muestras mientras se cocinaban a $50^{\circ} \mathrm{C}$. Los ingredientes añadidos tendieron a disminuir las medidas de viscosidad en la harina instantánea de yautía, mientras que en la de trigo tendieron a aumentarlas. Las porpiedades reológicas de la mezcla 15-85 siguieron el mismo patrón de la harina de trigo, pero la presencia de la harina instantánea de yautía tendió a disminuir sus valores.

Se tomaron medidas de reflectancia y de textura de las muestras después del examen amilográfico. Las primeras dan una indicación de la claridad de gel (paste clarity) y las últimas la dan la de su naturaleza. Las medidas de reflectancia fueron más altas para la harina de trigo, mientras que las de textura lo fueron para la mezcla 15-85.

\section{LITERATURE CITED}

1. Bean, M. L., and Osman, E. M., Behavior of starch during food preparation, II. Effects of different sugars on the viscosity and gel strength of starch pastes, Food Research. 24: 265, 1959.

2. D'Appolonia, B. L., Effect of bread ingredients on starch-gelatinization properties as measured by the amylograph, Cereal Chem. 49(5): 532-43, 1972.

3. Harai, J., Zaehringer, M. V., and Weise, A. C., Properties of wheat starch pastes containing components of cheddar cheese whey, Food Technol. 24(7): 803-8, 1970.

4. Hester, E. E., Briant, A. M., and Personius, C. J., The effect of sucrose on the properties of some starches and flours, Cereal Chem. 33: 91-101, 1956.

5. Leach, H. L., Starch: Chemistry and Technology, R. L. Whistler and E. F. Paschall, ed., Vol. I. Fundamental aspects 1965. Academic Press, N.Y.

6. Osman, E. M., Interaction of starch with other components of food systems, Food Technol. 29(4): 30-5 and 44, 1975.

7. _ and Dix, M. R., Effect of fats and nonionic surface-active agents on starch pastes, Cereal Chem. 37: 464, 1960.

8. Rodríguez-Sosa, E. J., and González, M. A., Preparation of instant tanier (Xanthasoma sp.) flakes, J. Agr. Univ. P.R. 61(1): 26-31, 1977. 